\title{
A survey of Himalayan rangeland weeds in Tinjure-Milke-Jaljale area, eastern Nepal
}

\author{
Dil Kumar Limbu ${ }^{1 *}$, Madan Koirala ${ }^{2}$ and Zhanhuan Shang ${ }^{3}$ \\ ${ }^{1}$ Central Campus of Technology, Dharan, T.U., Nepal \\ ${ }^{2}$ Central Department of Environmental Science, Kirtipur, T.U., Nepal \\ ${ }^{3}$ International Centre for Tibetan Plateau Ecosystem Management, Lanzhou University, China \\ *E-mail:dilklimbu@yahoo.com
}

\begin{abstract}
Eitht common rangeland weeds including Anaphalis contorta, Berberis erythroclada, Euphorbia wallichii, Potentilla lineate, Prunella vulgaris, Pteris aspericaulis, Senecio chrysanthemoides and Swertia pedicellata were recorded from the rangelands of Tinjure-Milke-Jaljale area in the present study, among which Senecio chrysanthemoides and Swertia pedicellata were the most obnoxious species responsible for the habitat degradation for wildlife, reduction in biodiversity, curtailment of forage resources and alternation of ecosystem and functions. The main reason for rapid weed invasion was the lack of awareness of the gravity of situation among the stakeholders hindering adoption of effective weed control measures.
\end{abstract}

Key words: Rangelands, weeds, description, distribution, density, control measures

\section{Introduction}

Rangelands are uncultivated lands that include grasslands, savannas, steppes, shrub-lands, deserts and tundra. The native vegetation of rangelands is predominantly grasses, forbs and shrubs (Kothmann, 1974). The rangelands cover about $40 \%$ of the world land, $60 \%$ of Hindu Kush Himalayas (HKH) and 12\% of land of Nepal (White et al., 2000; ICIMOD, 2009). The rangelands have supported pastoral livestock production and resources of livelihood in high altitude. It is increasingly recognised that rangeland ecosystems also provide significant services and benefits that go far beyond livestock production. On other hand, rangeland is degrading by unwanted plants, weeds.

Rangeland weeds are those plants which are unpalatable and unwanted native or invasive species that have adverse impacts on forage species in the grazing area. Climate change, introduction of new species, disturbance and fragmentation of land are causative factors for invasive weed infestation in rangelands.

Invasive weed species negatively impact rangelands throughout the world by displacing desirable species, altering ecological processes, reducing wildlife habitat, degrading systems, decreasing productivity and increasing management costs associated with herbicide application and pasture renovation (DiTomaso, 2000; Masters \& Sheley, 2001).

Invasion of many rangeland sites by non-native plants has been facilitated by multiple factors including overgrazing by domestic livestock, purposeful introduction of non-native 
plants for agricultural purposes, unintentional introduction of non-native plant seeds as a contaminate in crop seed, changes in fire frequency and intensity, and climatic changes that converge to cause shifts in plant community composition.

Rangeland weed identification and management in Himalayan rangelands has not been properly addressed in Nepal (Rajbhandari \& Joshi, 1998; Tiwari et al., 2005). Himalayan pastoralists have been facing great problem of weed infestation and its adverse affect on animal husbandry. No control measure has been taken into initiation. The main aim of the present study was documentation of Himalayan rangeland weeds in Tinjure-Milke-Jaljale (Referred as TMJ hereafter) area including their status, problem and control measures.

\section{Materials and Methods}

Study area

TMJ Mountain ridge lies as political border of Taplejung, Trhrathum and Sankhuwasabha districts of eastern Nepal (Map 1). Its geographical position is $27^{\circ} 17^{\prime} 35^{\prime \prime}$ to $27^{\circ} 30^{\prime} 28^{\prime \prime} \mathrm{N}$ latitude, $87^{\circ} 31^{\prime} 09^{\prime \prime}$ to $87^{\circ} 38^{\prime} 14^{\prime \prime} \mathrm{E}$ longitude, extended from 3000 to $4500 \mathrm{msl}$ altitude. Its average annual temperature is $10-15^{\circ} \mathrm{C}$ and average annual rainfall $2050 \mathrm{~mm}$. The area is under heavy human and livestock (yak, cattle, buffaloes, sheep and goats) pressures (Oli, 2002). It serves as habitat corridor between Makalu-Barun Conservation Area towards northwest and Kanchenjunga Conservation Area towards north-east, both of which touch the Qomolongma Biosphere Reserve in Tibet (Koirala, 2002). The mountain ridges across Tinjure-Milke-Jaljale (TMJ) are the natural niches for 27 rhododendron species.

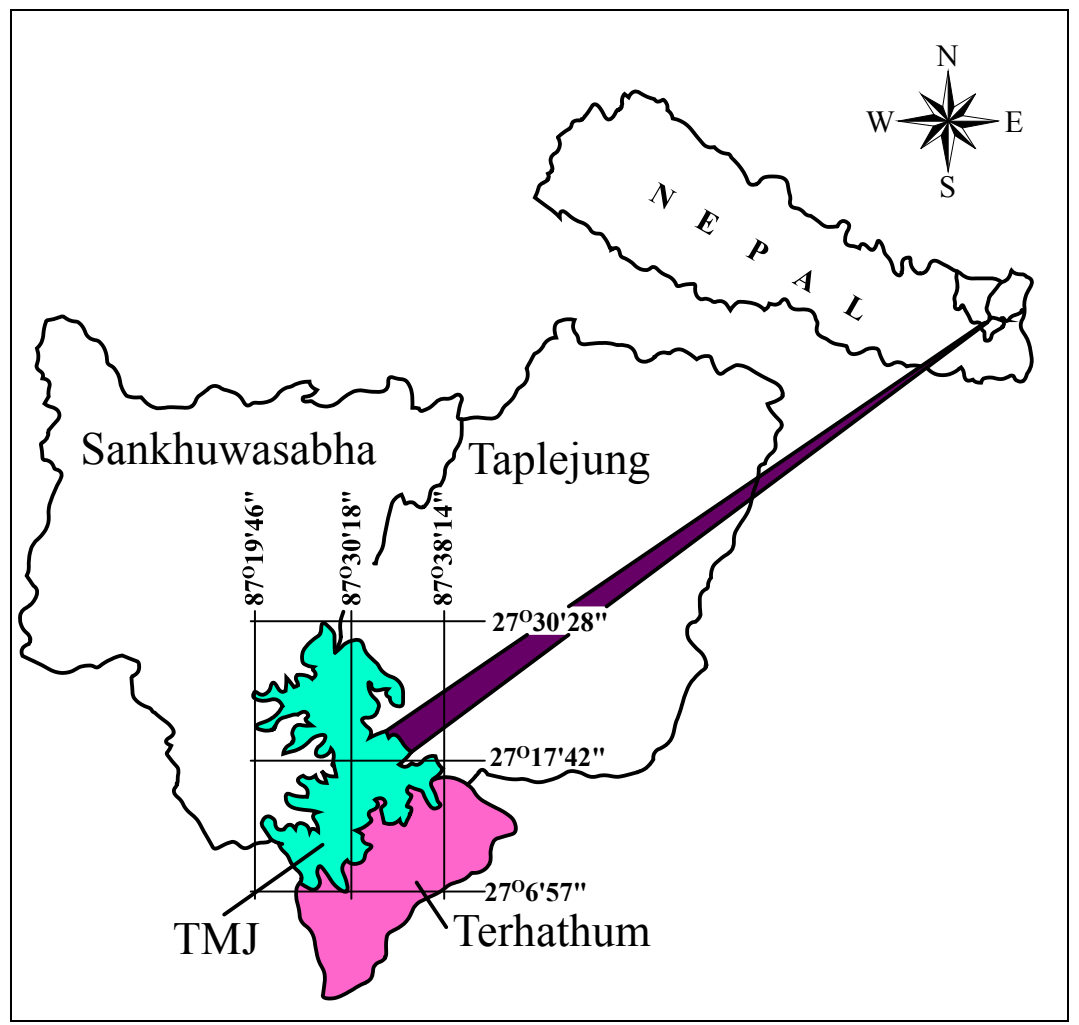

Map 1. Tinjure-Milke-Jaljale (TMJ) study area. 
Field visits were carried out between August and September, 2010 and 2011 in study area. Five senior citizens, 10 senior herdsmen and 2 social activists were interviewed based on structured questionnaire. Rangeland weeds were collected and identified using available literature (Press et al., 2000; MoFSC, 2002; Polunin \& Stainton, 2003). Their coverage, invasion year, adverse effect and life form were noted from interviews, questionnaires and field visits. Field visit route was Basantapur $(2250 \mathrm{~m})$, Tute deurali $(2475 \mathrm{~m})$, Ghurbise $(2660 \mathrm{~m})$, Pancha pokhari $(2850 \mathrm{~m})$, Tinjure $(2900 \mathrm{~m})$, Phedi $(2670 \mathrm{~m})$, Chouki $(2690 \mathrm{~m})$, Mangalabare (2635 m), Shreemane, Bhalukhop, Lampokhari (2800 m), Gupha $(2890 \mathrm{~m})$, Jorpokhari (2905 m), Milke (3016 m), Lampokhari (Thadelung) (2880 m), Khoping (3000 $\mathrm{m})$, Harkate (3200 m), Dobate (3450 m), Gorujure (3600 m), Hile, Gidde, Manebhanjyang (3400 m), Khambole (3500 m), Gurgutte (Tree line $3850 \mathrm{msl})$, Thumki (3950 m), Bhakari chhiruwa (4000 m) and Jaljale pokhari (4100 msl).

Density, frequency and abundance of some dominant rangeland weeds were determined by random quadrat $\left(1 \times 1 \mathrm{~m}^{2}\right.$ size $)$ method.

\section{Results and Discussion}

Highly abnoxious rangeland weeds recorded in the present study were as follows.

1. Anaphalis contorta (D. Don) Hook. f.

Family: Asteraceae

Locale name: Bukki

Habit/Habitat: perennial, forest and grazing ground.

Distribution: Afghanistan to SW China, 1800-3500 m, Native to Asia temperate, China

Description: A small herb with terminal flower cluster, with slender woolly stems with many overlapping linear leaves which are contrastingly green above and white-woolly beneath. Flower compact $1.5 \mathrm{~cm}$. across; flower-head $3 \mathrm{~mm}$ across, with shining white involucral bracts 1-2 mm. Leaves with enrolled margins, mostly $1-2 \mathrm{~cm}$ by $1-3 \mathrm{~mm}$ wide; basal leaves densely clustered, ovate, white-woolly; stem usually branched from the base.

Field observation: It was not a problematic weed in Basantapur $(2280 \mathrm{~m})$ to Milke (3000 $\mathrm{m})$. Its population was dense in Harkatte $(3200 \mathrm{~m})$ and Dobate $(3400 \mathrm{~m})$.

2. Berberis erythroclada Ahrendt

Family: Berberidaceae

Locale name: Sidhdiko Chutro

Habit/Habitat: Perennial, shrubberies, forming thickets on grazing land

Distribution: Central Nepal to S.E. Tibet, 3000-4000 m

Description: A densely branched low shrub 30-100 cm, with shinning dark red, grooved, hairless stem and branched, obovate leaves with 5-15 stiff spiny teeth. Flowers yellow, usually solitary, on slender stalks longer than the leaves; petal 5-7 mm. Leaves 1-2 cm; stem spines slender $5-10 \mathrm{~mm}$. Fruit red, $1.5 \mathrm{~cm}$.

Field observation: It appeared from Khoping $(3100 \mathrm{~m})$, Gurgutte $(3750 \mathrm{~m})$ to Thumki $(3900 \mathrm{~m})$ on the route of Jaljale Himal pastureland. Plant body was spiny and therefore cattle avoided it. It hindered the way of herdsmen and cattle. 
3. Euphorbia wallichii Hook. f.

Family: Euphorbiaceae

Locale name: Dudhe

Habit/Habitat: perennial herb, open slopes, grazing grounds, rocky mountains.

Distribution: Afghanistan to S.W. China, 2500-4000 m, Jaljala area, east Nepal, Native to western and central Himalaya

Description: $2 \mathrm{ft}$ tall, very leafy stems with yellow flower heads in a more or less flattopped cluster, each flower head with 3-4 large rounded or ovate acute golden - yellow bracts. involuvre with large kidney shaped glands and with hairs within; bracts $1-3 \mathrm{~cm}$. Leaves $5-10 \mathrm{~cm}$, linear to narrow-elliptic; stems several, unbranched $30-60 \mathrm{~cm}$ stem, Fruit $8 \mathrm{~cm}$, seeds blue-grey. Flowering is in late spring.

Field observation: It prefers to grow on rocky pastureland. It was found above $3200 \mathrm{~m}$ altitude in TMJ area. It is not a much problematic weed to rangelands.

4. Potentilla lineata Trev.

Family: Rosaceae

Locale name: Mulapate (Bajradanti)

Habit/Habitat: Perennial herb, open grazing ground

Distribution: 2000-3200 m, South China, Bhutan, Nepal

Description: $5-40 \mathrm{~cm}$ tall, radical leaves with pubescent petiole, leaf blade interrupted pinnate with 5-13 pairs of leaflets; yellow flowers $1.5 \mathrm{~cm}$ in diameter with gland-tipped, sepals entire at margin.

Field observation: Potentilla lineata was densely populated at Mangalabare $(2635 \mathrm{~m})$ and Chauki (2690 m) of TMJ. However it was not a great problem of TMJ rangeland.

5. Prunella vulgeris $L$.

Family: Labiatae

Locale name: Ban silam

Habitat: perennial herb, open and slope rangeland

Distribution: Afghanistan to Bhutan, 1500-3600 m

Description: Flower bright blue-violet, rarely white or pink, in dense cylindrical terminal head $2.5-5 \mathrm{~cm}$ long, usually with broad ovate, purplish, overlapping bracts, with purplish calyx, and with a pair of leaves immediately below and spreading beyond the inflorescence. Flowers $1.5 \mathrm{~cm}$ long, in whorls of 6 ; corolla 2-lipped; the throat closed after flowering.

Field observation: It rarely appeared at Chowki $(2690 \mathrm{~m})$ and Mangalbare $(2635 \mathrm{~m})$ but Khoping pokhari $(3000 \mathrm{~m})$ and Harkate $(3200 \mathrm{~m})$ area was covered dominantly by Prunella vulgeris.

6. Pteris aspericaulis Wall. ex J.Agardh

Family: Pteridaceae

Locale name: Unyu

Habitat: perennial herb, open and slope rangeland

Distribution: Afghanistan to Bhutan, 1500-2900 m

Description: Segments minutely apiculate,stipe more or less asperous, at least near the base. Pink-tinged forms were more common than all green ones. It had a long frond with many pinnae. 
Field observation: It covered rangelands at Mangalbare $(2650 \mathrm{~m})$, Shreemane $(2800 \mathrm{~m})$, Bhalukhop and Lampokhari $(2800 \mathrm{~m})$. Usually, it was scattered on sloppy area and grew in clusters.

7. Senecio chrysanthemoides DC.

Family: Asteracea

Locale name: Tori phule

Habitat: perennial, shrubberies, open slope rangeland, fertile land

Distribution: Pakistan to South-West China, 2400-3600 m, Gupha pokhari area, Native to Western Himalaya.

Description: 2-4 feet tall herb, lower leaves lyrate-pinnatifid with an auricled petiole, upper leaves sessile, bipinnatifid, base amplexicaul, surface white pubscent, numerous yellow flower head, flower head with 10-12 spreading ray florets, Ray floret few; disc florets many with shortly 5 fid tubular corollas. Achenes smooth.

Flowering: March-September; Fruiting: June-November

Field observation: Senecio chrysanthomoides was a serious threat to TMJ rangeland area. Its infestation was fast in open rangeland area and degraded pastureland. It grows mainly in fertile, plain land and leave place of temporary sheds. Its visually estimated density was about 40 plants $/ \mathrm{m}^{2}$ in Gupha and Shreemane rangeland area. It grew luxuriantly in Mangalabare (2635 m), Shreemane, Bhalukhop, Lampokhari (2800 m), Gupha (2890 m), Jorpokhari (2905 m) and Milke (3016 m).

\section{Swertia pedicellata Banerji}

Family: Gentianaceae

Locale name: Bhale chiraito

Habitat: perennial herb, open and slope rangeland.

Distribution: Northeastern India and Eastern Nepal, 2500-3500 m.

Description: $30 \mathrm{~cm}$ tall stem square with opposite and sessile leaves, flower brownish and propagated by seeds.

Field observation: Swertia pedicellata was an emerging problem on TMJ rangeland area. It was most dense and problematic weed. Estimated density was about 126 plants $/ \mathrm{m}^{2}$ in TMJ rangeland and prefered to grow on less disturbed area. Usually, its dense population occurred at Mangalbare $(2650 \mathrm{~m})$, Lampokhari $(2800 \mathrm{~m})$, Gupha (2890 m), Jorpokhari (2905 m) and Milke (3016 m).

\section{Rangeland weeds controlled measures}

Controlled measures of rangeland weeds are various methods viz. mechanical, chemical, biological and cultural.

\section{Mechanical}

Mechanical control techniques either remove the entire plant or physically damage shoots, roots, or root crowns of plants to the point where they can no longer survive. Mechanical control methods include hand-pulling, hoeing, tilling, mowing, grubbing, chaining, cutting, and bulldozing. These techniques can be expensive, and they disrupt the soil, creating disturbed sites prone to invasion. Swertia pedicellata and Senecio chrysanthemoides DC. were partially removed by mechanical method by local herdsmen. However it is not planned 
and regular. Generally, herdsmen up-rooted weeds at the surroundings of their cattle sheds and on their ways.

\section{Cultural}

Cultural control practices in rangelands most often include fire, grazing, or revegetation efforts. All these strategies require manipulating disturbance regimes to suppress invasive plants and to enhance desirable vegetation. In TMJ rangeland, grazing and firing practices controlled weeds to some extent.

\section{Biological}

Classical biological control agents (plants, animals or microbes) are used on some rangeland invasive plants that involve relocation of natural enemies of the invasive plant, typically insects, from their native habitats onto plants in their invaded habitats. The long-term goal of these programs is to exert sufficient stress on the target plant to reduce plant competitive ability and dominance.

\section{Chemical}

Herbicides are used for controlling the target weeds on rangelands. These are generally classified by their mode of action, selectivity, and location of application (foliar or soil). Soil-applied herbicides generally target emerging seedlings, whereas foliar-applied herbicides control plants ranging from seedlings to fully mature plants.

There were 8 highly noxious rangeland weeds in Tinjure-Milke-Jaljale rangeland area. Two species, Swertia pedicellata and Senecio chrysanthemoides, out of 8 were most problematic weeds. About 300 weeds are reported from USA rangeland, among them some of the most problematic weeds are cheatgrass (Bromus tectorum), medusahead (Taeniatherum caputmedusae) and leafy spurge (Euphorbia esula) (DiTomaso et al., 2010). Similarly, about 160 weeds are reported from Australian rangeland, among them most problematic weeds are Mimosa pigra and gamba grass (Andropogon gayanus) (Martin et al., 2006).

Rangeland weeds degrade rangeland ecosystem and socio-economic conditions. Furthermore, invasive rangeland species can decrease wildlife habitat and forage, deplete soil and water resources, and reduce plant and animal diversity.

Swertia pedicellata grows in colonial habitat and completely dominate over forages. It is unpalatable because of bitter taste and invasion speed up at apt environment. Aforementioned two species are troublesome to herdsmen in TMJ rangeland. These weeds' population and invasion are multiplying year by year.

There are five kinds of rangelands on the basis of ownership (Limbu, 2011) in the study area. Generally, rangeland owners do not rear cattle or take responsibility to control weed infestation on rangeland. Transhumant pastoralists are not serious for weed controlling because they use the rangeland once in a year. Similarly government and rangeland development institutes have no plans for it. Chemical and biological weed control measures have not been practiced yet in the study area. Mechanical and cultural methods are practiced very rarely by herdsmen but not as a planning. Consequently, individuals as well as government have been losing large amount of money. In developed countries invasiveweeds management strategies use an Integrated Pest Management (IPM) approach. The 
magnitude and complexity of rangeland invasions, combined with the costs for their control, most often necessitate the use of a combination of mechanical, cultural, biological, or chemical methods (Masters \& Sheley, 2001). This paper is not a complete work on weeds and weed problems of high altitude rangeland area therefore it needs more study on economic and ecological impacts of weeds on rangelands.

\section{Acknowledgements}

Authors would like to acknowledge informants and herdsmen of study area, Tinjure-MilkeJaljale. Similarly, authors are thankful to personnel of National Herbarium and Plant Laboratories, Godawari, Lalitpur, Nepal for plant identification. The first author is grateful to the University Grants Commission, Nepal for the research fellowship.

\section{References}

DiTomaso, J.M. 2000. Invasive weeds in rangelands: species, impacts, and management. Weed Sci. 48: 255-265.

DiTomaso, J.M., R.A. Masters \& V.F. Peterson. 2010. Rangeland invasive plant management. Rangelands 32(1): 43-47.

ICIMOD, 2009. Climate Change and the Hindu Kush-Himalayan Rangeland information sheet $\# \mathbf{8} / \mathbf{0 9}$

Koirala, M. 2002. Environmental determinants of the livelihood related food production system in a mid-Himalayan landscape (Tinjure-Milke region), East Nepal. Ph.D. Thesis, Jawaharlal Nehru University, New Delhi, India.

Kothmann, M.M. 1974. Grazing management terminology. Journal of Range Management 27: 326-327.

Limbu, D.K. 2011. Rangeland ownership of Himalayan region of eastern Nepal. National Foundation for Development of Indigenous Nationalities (NFDIN), Kathmandu.

Martin, T.G., S. Campbell \& S. Grounds. 2006. Weeds of Australian rangelands. Rangeland Journal 28:3-26.

Masters, R.A. \& R.L. Sheley. 2001. Principles and practices for managing rangeland invasive plants. J. Range Manag. 54: 502-517.

MoFSC. 2002. Pteridophytes of Nepal. Bull. Dept. of Plant Resources No. 19. National Herbarium \& Plant Laboratories Godavary, Lalitpur, Nepal.

Oli, K.P. 2002. An assessment of Tinjure, Milke and Jaljale (TMJ) area of eastern Nepal. Internal Document, IUCN, Nepal.

Polunin, O. \& A. Stainton. 2003. Flowers of the Himalaya. Oxford University Press, New Delhi.

Press, J.R., K.K. Shrestha \& D.A. Sutton. 2000. Annotated Checklist of the Flowering Plants of Nepal. The natural History Museum, London.

Rajbhandari, K.R. \& R. Joshi. 1998. Crop weeds of Nepal. Natural History Society of Nepal, Kathmandu.

Tiwari, S., B. Adhikari, M. Siwakoti \& K Subedi. 2005. An inventory and assessment of invasive alien plant species of Nepal. IUCN, Kathmandu, Nepal.

White, R., S. Murray \& M. Rohweder. 2000. Pilot Analysis of Global Ecosystems Grassland Ecosystems. World Resources Institute: Washington D.C. 